\title{
БЕЛЬГИЯ: КОНЕЦ «ШВЕДСКОЙ КОАЛИЦИИ»
}

Аннотация. Статья посвящена распаду правящей коалиџии Бельгии 2014-2018 г2. вследствие неприятия одной из коалищионных партий, правопопулистским «Новым фламандским альянсом», позищии остальных партий по вопросу присоединения страны к Глобальному договору о безопасной, упорядоченной и легальной миграции. Автор рассматривает бельгийский случай, как пример успешной секьюритизации миграџионных проблем правопопулистскими партиями в преддверии парламентских выборов.

Ключевье слова: Бельгия, Новый фламандский альянс, миграџия, секьюритизаџия, правый популизм.

Подписание Глобального договора о безопасной, упорядоченной и легальной миграции привело к многочисленным протестам в ряде государств Европейского союза. Несколько стран (в том числе Чехия, Венгрия и Польша) отказались к нему присоединиться, общество многих стран ЕС оказалось расколото ${ }^{1}$. В Бельгии же противоречия, связанные с подписанием т.н. Марракешского пакта, привели к распаду правящей коалиции.

\section{Регионалисты в правительстве}

Вхождение в коалицию было одним из крупных успехов партии «Новый фламандский альянс» (НФА, N-VA). Правопопулистская партия, стоящая на позициях фламандского регионализма, во многом набрала популярность в последние годы за счёт контраста с более радикальной правой партией «Фламандский интерес». Хотя обе опираются на политическую традицию т.н. «Фламандского движения» (движения за бо́льшую автономию и даже независимость Фландрии), НФА избежал «санитарного кордона» и оказался встроенным в политическую систему Бельгии, в отличие от своего более маргинального конкурента. Это обусловлено и различным происхождением партий: НФА - один из осколков партии «Народный союз», активной на бельгийской политической сцене ещё с 1950-х гг., в то время как ФИ не может похвалиться долгой историей парламентского участия и не в состоянии избежать ассоциаций с крайне правыми и правоэкстремистскими группами.

На выборах 2014 г. НФА получил абсолютное большинство голосов во Фландрии (в Бельгии сосуществуют две параллельных партийных системы, франко- и нидерландоязычная, действующие каждая в «своём» регионе). Лидер Альянса Барт Де Вейвер стал бургомистром Антверпена. С учётом таких результатов стало очевидно, что без участия фламандских регионалистов правительство сформировать не получится, и представителям Альянса были от-

(С Осколков Пётр Викторович - научный сотрудник Отдела исследований европейской интеграции ИЕ РАН. Adpec: 125009, Россия, Москва, ул. Моховая, д. 11, стр. 3; старший преподаватель факультета мировой политики МГУ им. М.В. Ломоносова: преподаватель кафедры сравнительной политологии МГИМО МИД России. E-mail: p.oskolkov@inno.mgimo.ru.

DOI: http://dx.doi.org/10.15211/vestnikieran120196569

${ }^{1}$ См.: Потемкина О.Ю. Глобальный договор о миграции - успех или провал? Научно-аналитический вестник ИЕ РАН. 2018, №6. С. 86-91; Биссон Л.С. Интеграция мигрантов в ЕС и России: разница в подходах. Научноаналитический вестник ИЕ РАН. 2018, №6. С. 112-118. 
даны ключевые портфели министров обороны, внутренних дел и финансов, а также посты госу-дарственного секретаря (статус, аналогичный министру, но без права голоса в совете минист-ров) по вопросам убежища, миграции и упрощения административных процедур и государственного секретаря по борьбе с бедностью, мошенничеством и научной политике. Партнёрами регионалистов стали партии «Открытые фламандские либеральные демократы» (Open VLD), «Христианские демократы и фламандцы» (CD\&V), а также франкоязычное либерально-центристское «Реформаторское движение» (MR), представитель которого Шарль Мишель был назначен премьер-министром.

В соответствии с бельгийской политической традицией, правительство получило неформальное название в соответствии с цветами, символизирующими составившие его партии. Так, в 1999-2003 гг. страной правила «радужная» коалиция (regenboogcoalitie) из либералов («синих»), социалистов («красных») и зелёных. В 2014 г. правительство сформировали четыре партии, и оно было названо «шведским»: фламандские и валлонские либералы были обозначены синим, Новый фламандский альянс - жёлтым (по цвету фламандского флага - чёрный лев на жёлтом фоне), христианских демократов же символизировал крест. Символы и цвета сложились в шведский флаг.

Распад «шведской коалиции» предсказывался и ранее. Так, в 2017 г. в ведущем бельгийском общественно-политическом журнале «Knack» была опубликована статья известного валлонского политолога и писателя Жюля Гёда (Jules Gheude) под названием «2018: конец шведской коалиции и государства» ${ }^{1}$. Автор предсказывал распад правительства в грядущем году (правда, по другой причине - из-за разногласий по поводу энергетической политики) и последующий распад страны в условиях отсутствия дееспособного правительства. Как мы увидим далее, эти прогнозы оправдались лишь частично. (И стоит вспомнить, что в 2010 г. после «падения» кабинета Ива Летерма Бельгия существовала без правительства в течение 541 дня и всё же не развалилась).

Наибольшее недовольство коллег-либералов вызывал госсекретарь по вопросам убежища и миграции Тео Франкен. Он дал для этого немало поводов: в 2014 г. присутствовал в качестве почётного гостя на 90-летнем юбилее Боба Мааса, видного члена коллаборационистского Фламандского национального союза и впоследствии председателя Фламандского военного ордена - праворадикальной парамилитарной организации. В том же году в прессу просочилась личная переписка госсекретаря, в которой он выражал сомнения в «добавочной стоимости» иммигрантов из стран Магриба. В сентябре 2017 г. Т. Франкен опубликовал в Твиттере запись, посвящённую аресту 14 иммигрантов в Брюсселе, сопроводив её меткой \#opkuisen - буквально «вычистить» ${ }^{2}$. Понятно, что такое поведение не придало Франкену привлекательности в глазах либеральных коллег.

\section{От «шведского кабинета» к «коалиции Марракеш»}

Тем не менее, распад коалиционного правительства был вызван не противоречиями по поводу энергетики и не провокативным поведением фламандских регионалистов, а позицией премьер-министра и остальных партий по поводу Глобального договора о безопасной, упорядоченной и легальной миграции (также неофициально называемого Марракешским пактом ООН). Договор был утверждён 10 декабря 2018 г. на Межправительственной конференции

\footnotetext{
${ }^{1}$ Gheude J. 2018: het einde van de Zweedse coalitie? (En ook van het land?) Knack. 29.12.2018. URL: https://www. knack.be/nieuws/belgie/2018-het-einde-van-de-zweedse-coalitie-en-ook-van-het-land/article-opinion-944843.html.

2 Arnoudt R. Theo Francken haalt zich digitale woede op de hals met «\#opkuisen». VRT. 14.09.2017. URL: https://www.vrt.be/vrtnws/nl/2017/09/14/theo-francken-haalt-zich-digitale-woede-op-de-hals/
} 
ООН в Марракеше ${ }^{1}$. Несмотря на то, что документ носит рекомендательный характер, процедура его подписания и последующей ратификации странами - членами ООН была максимально использована в своих целях правопопулистскими и праворадикальными партиями и движениями в Евросоюзе.

Председатель «Нового фламандского альянса» Барт Де Вейвер заявил, что в случае подписания договора премьер-министром Бельгии министры от этой партии уйдут в отставку. Премьер Шарль Мишель подтвердил своё намерение подписать документ, и члены НФА 8 декабря покинули правительство. Поскольку следующие парламентские выборы запланированы уже на 26 мая 2019 г., новое правительство пока решили не формировать, и освободившиеся портфели были перераспределены между представителями других партий. Новая коалиция получила название «оранжево-синей» (синий, как уже было упомянуто, - цвет либералов, а оранжевый используется для обозначения христианских демократов). Также по аналогии с цветами флага Нью-Йорка правительство стали называть «коалицией Нью-Йорк», а противники Мишеля стали использовать термин «коалиция Марракеш». Министра внутренних дел Жана Жамбона сменил представитель христианских демократов Питер Де Крем, функции министра финансов Йохана Ван Овертфелдта получил бывший министр по вопросам развития и телекоммуникаций, либерал-демократ Александер Де Кроо, а функции министра обороны министр иностранных дел, представитель «Реформаторского движения» Дидье Рейндерс. Нового министра финансов Де Кроо сменил на посту министра по вопросам развития и телекоммуникаций либерал-демократ Филип Де Баккер. От постов госсекретарей в новом правительстве было решено отказаться, полномочия госсекретарей - представителей НФА были распределены между остальными министрами. Таким образом, в «оранжево-синем» правительстве появилось только два новых лица - Де Крем (CD\&V) и Де Баккер (Open VLD).

Поскольку НФА - крупнейшая парламентская партия в текущем составе парламента, получившееся правительство представляло собой кабинет меньшинства, чего в истории Бельгии не бывало. Уже через десять дней после своего формирования «оранжево-синяя» коалиция была вынуждена уйти в отставку из-за того, что «Новый фламандский альянс» не поддержал проект бюджета на 2019 г. Кроме Альянса, правительство Мишеля подвергли сокрушительной критике находящиеся в оппозиции социалисты (фламандкие и валлонские) и зелёные. После консультаций короля с лидерами других партий стало ясно, что ни одна партия, кроме НФА и «Фламандского интереса», не считает досрочные выборы необходимыми, поэтому фактически в стране осталась «оранжево-синяя коалиция», ставшая «правительством текущих дел»- т.е. его полномочия существенно ограничены.

Таким образом, НФА удалось фактически обрушить бельгийскую политическую конструкцию и продемонстрировать неспособность коалиционных партнёров править без регионалистов. Как бы то ни было, следующие выборы пройдут уже в мае. Позиции Альянса весьма тверды: по результатам различных опросов, проведённых в декабре 2018 г., за эту партию готовы голосовать 28-30\% фламандцев ${ }^{2}$. Вопрос, однако, в том, будет ли НФА привлечён к формированию следующего правительства: такой нестабильный и неконструктивный союзник мало кому может понравиться, поэтому более вероятно, что НФА станет крупнейшей партией оппозиции.

Б. Де Вейвер очевидно стремился возложить на Ш. Мишеля и «Реформаторское движение» вину за распад коалиции. На своей пресс-конференции он заявил, что «Мишель взойдёт

\footnotetext{
${ }_{1}^{1}$ Полный официальный текст Договора доступен по ссылке: http://undocs.org/ru/A/CONF.231/3.

${ }^{2}$ Matthijs H. Michel II in 2019: een rustige wandeling of een hell of a race tot mei? Knack. 01.01.2019. URL: https:// www.knack.be/nieuws/belgie/michel-ii-in-2019-een-rustige-wandeling-of-een-hell-of-a-race-tot-mei/article-opinion1412287.html.
} 
на трап самолёта в аэродроме Мелсбрук как премьер шведской коалиции, а приземлится как премьер коалиции Марракеш. (...) Мы не против мигрантов или миграции, но мы против сегодняшнего европейского миграционного хаоса» ${ }^{1}$, подчёркивая таким образом, что премьерминистр променял внутриполитическую стабильность на исполнение туманных внешнеполитических обязательств. Однако Мишелю удалось предупредить такие обвинения, вовремя заявив о сохранении (переформатированного) правительства и поблагодарив «Новый фламандский альянс» за конструктивную работу в течение последних четырёх лет. Причины ухода своих единомышленников из правительства Де Вейвер сформулировал следующим образом: «С того момента, как Мишель летит в Марракеш без нашего согласия, он фактически увольняет нас из правительства. Мы формально уведомили премьера о том, что мы не согласны с Договором. Другие партии заявили, что согласие НФА не нужно для того, чтобы лететь в Марракеш. Мы так не считаем» ${ }^{2}$.

«Новый фламандский альянс» не был одинок в своём неприятии «Марракешского пакта». Представители другой бельгийской правопопулистской партии «Фламандский интерес» совместно с лидером французского «Национального объединения» Марин Ле Пен и американским политиком-республиканцем Стивеном Бэнноном выступили на митинге в Брюсселе 8 декабря с осуждением Договора ${ }^{3}$. Также в Брюсселе 15 декабря состоялся «Марш против Марракеша», организаторами которого выступили несколько правых организаций, такие как «Форпост», «Щит и друг», «Католический союз фламандских студентов» и «Союз студентовнационалистов». Марш был изначально запрещён брюссельским региональным правительством, а премьер-министр Брюссельского столичного региона Руди Вервоорт назвал его «коричневым маршем» ${ }^{4}$. Однако Государственный совет отменил этот запрет. На марше звучали такие лозунги как «левые крысы, пакуйте вещи», «сначала наш народ», «нет джихаду в нашей стране», «мы устали, закроем границы» и «Мишеля в отставку» 5 .

\section{Выводы}

Пример Бельгии свидетельствует об извечном стремлении правопопулистских партий к актуализации и секьюритизации иммиграционных проблем и использовании антииммигрантского дискурса для повышения своей внутриполитической привлекательности. В расчёте на грядущие электоральные преимущества подобные партии могут пожертвовать даже министерскими портфелями - тем более, если до новых парламентских выборов осталось совсем немного, а у партии сохраняется парламентское представительство.

\section{Список литературы}

Биссон Л.С. Интеграция мигрантов в ЕС и России: разница в подходах. Научно-аналитический вестник ИЕ РАН. 2018, №6. С. 112-118. DOI: 10.15211/vestnikieran62018112118

Потемкина О.Ю. Глобальный договор о миграции - успех или провал? Научно-аналити-

\footnotetext{
${ }^{1}$ Цит. по: De Wever: «Michel zal opstijgen als premier van de Zweedse coalitie maar landen als premier van de Marrakech-coalitie». Het Laatste Nieuws. 08.12.2018. URL: https://www.hln.be/nieuws/binnenland/de-wever-michel-zalopstijgen-als-premier-van-de-zweedse-coalitie-maar-landen-als-premier-van-de-marrakech-coalitie af5e4c653/

${ }_{2}^{2}$ Цит. по: Schram E., Vermeyren K. De Zweedse coalitie is gevallen, maar wie is verantwoordelijk? Knack. 09.12. 2018. URL: https://www.knack.be/nieuws/belgie/de-zweedse-coalitie-is-gevallen-maar-wie-is-verantwoordelijk/articlelong read-1404131.html/

${ }^{3}$ BQE. 2018. N 12156. 10.12.

${ }^{4}$ La Région bruxelloise confirme l'interdiction de la «Marche contre Marrakech». Le Soir. 13.12.2018. URL: https:// www.lesoir.be/195430/article/2018-12-13/la-region-bruxelloise-confirme-linterdiction-de-la-marche-contre-marrakech.

5 Bruxelles: des débordements lors de la «marche contre Marrakech». Le Soir. 16.12.2018. URL: https://www. lesoir.be/195898/article/2018-12-16/bruxelles-des-debordements-lors-de-la-marche-contre-marrakech-direct.
}

Научно-аналитический вестник ИЕ РАН, 2019, №1 
ческий вестник ИЕ РАН. 2018, №6. С. 86-91. DOI: 10.15211/vestnikieran620188691

\section{References}

Arnoudt R. Theo Francken haalt zich digitale woede op de hals met «\#opkuisen». VRT. 14.09. 2017. URL: https://www.vrt.be/vrtnws/nl/2017/09/14/theo-francken-haalt-zich-digitale-woede-opde-hals/

BQE. 2018. N 12156. 10.12.

Bruxelles: des débordements lors de la «marche contre Marrakech». Le Soir. 16.12.2018. URL: https://www.lesoir.be/195898/article/2018-12-16/bruxelles-des-debordements-lors-de-la-marchecontre-marrakech-direct.

De Wever: «Michel zal opstijgen als premier van de Zweedse coalitie maar landen als premier van de Marrakech-coalitie». Het Laatste Nieuws. 08.12.2018. URL: https://www.hln.be/nieuws/ binnenland/de-wever-michel-zal-opstijgen-als-premier-van-de-zweedse-coalitie-maar-landen-alspremier-van-de-marrakech-coalitie af5e4c653/

Gheude J. 2018: het einde van de Zweedse coalitie? (En ook van het land?) Knack. 29.12.2018. URL: https://www.knack.be/nieuws/belgie/2018-het-einde-van-de-zweedse-coalitie-en-ook-vanhet-land/article-opinion-944843.html.

La Région bruxelloise confirme l'interdiction de la «Marche contre Marrakech». Le Soir. 13.12. 2018. URL: https://www.lesoir.be/195430/article/2018-12-13/la-region-bruxelloise-confirme-linterdiction-de-la-marche-contre-marrakech.

Matthijs H. Michel II in 2019: een rustige wandeling of een hell of a race tot mei? Knack. 01.01. 2019. URL: https://www.knack.be/nieuws/belgie/michel-ii-in-2019-een-rustige-wandeling-of-eenhell-of-a-race-tot-mei/article-opinion-1412287.html.

Schram E., Vermeyren K. De Zweedse coalitie is gevallen, maar wie is verantwoordelijk? Knack. 09.12.2018. URL: https://www.knack.be/nieuws/belgie/de-zweedse-coalitie-is-gevallenmaar-wie-is-verantwoordelijk/article-longread-1404131.html/

\section{Belgium: collapse of the «Swedish coalition»}

Author. Petr Oskolkov, Research Associate, Department of European Integration Studies, Institute of Europe, Russian Academy of Sciences. Address: 11-3, Mokhovaya str., Moscow, Russia, 125009. Lecturer, Department of Comparative Politics, MGIMO University; Senior Lecturer, Department of Regional Issues of World Politics, Lomonosov Moscow State University. E-mail: p.oskolkov@inno.mgimo.ru.

Abstract. The paper is dedicated to the collapse of the Belgian ruling coalition of 2014-2018 because of the dissatisfaction of the New Flemish Alliance, one of the coalition partners, with other parties' position regarding the signing of the Global Compact for Safe, Orderly and Regular Migration. The author sees the Belgian case as an example of successful securitization of migration problems by right-wing populist parties on the threshold of the parliamentary election.

Key words: Belgium, New Flemish Alliance, migration, securitization, right-wing populism.

DOI: http://dx.doi.org/10.15211/vestnikieran120196569 